\title{
GENDER QUOTAS ON BOARDS - IS IT TIME FOR AUSTRALIA TO LEAN IN?
}

\section{Peta Spender*}

This article examines whether Australia should introduce a gender quota on ASX 200 boards. Although existing institutional arrangements favour voluntary initiatives, Australia may be at a critical juncture where two factors - the public, pragmatic nature of the statutory regulation of corporations in Australia and the current salience of gender as a political issue - may favour the introduction of a quota. In particular, Australian policy-makers may be amenable to change by observing initiatives from other jurisdictions. It is argued that we should maintain a healthy scepticism about functionalist arguments such as the business case for women on boards. Rather, we should invoke enduring justifications such as equality, parity and democratic legitimacy to support a quota. The optimal design of an Australian gender board quota will be also be explored.

\section{INTRODUCTION}

This article contemplates whether the time is ripe for Australia to lean in ${ }^{1}$ to the option of mandatory gender board quotas and perhaps to impose them. The background to the debate about gender quotas on boards and possible future directions will be discussed. In Australia, although there is a tradition of gender policy initiatives such as the Work Gender Equality Act (Cth) 2013 (WGE Act), and some voluntary initiatives designed to boost female representation, path dependence tends to perpetuate existing institutional arrangements which favour male-dominated boards. The path created by existing institutional

\footnotetext{
* Professor of Law, ANU College of Law, Australian National University. The author wishes to thank Deakin Law School and the Alexander von Humboldt Foundation for organising the International Corporate Governance and Law Forum in October 2014; the participants for their enthralling insights; the editors for their stellar editorial assistance and Professor Jean du Plessis for his valuable contributions to the debate about mandatory board quotas.

${ }^{1}$ The term 'lean in' was coined by Sheryl Sandberg, who invited women to lead by raising their hand and stop holding back. She urged women to 'lean in' rather than 'pull back' from opportunities: Sheryl Sandberg, Lean In: Women, Work, and the Will to Lead (W H Allen, 2013).
} 
arrangements is counterbalanced by diffusion, where we observe the experimentation that has occurred in other jurisdictions about gender quotas on boards and borrow ideas to form our own policies.

It will be argued that, while functionalist arguments dominate the literature and the debate in business circles regarding gender quotas on corporate boards, the most enduring justifications are normative, and based on equality, parity and democracy. Broadly stated, functionalist arguments contend that women make a measurable difference to corporate performance; the arguments reach their pinnacle in the business case which posits that having women on boards is good for business. This article argues that the business case is often misconceived and we should maintain a healthy scepticism about its claims. This leads to a broader question about what type of representation we can expect from women on boards and it is contended that the symbolic representation of women is sufficient because it signals a change to traditional conceptions of authority and citizenship.

Does the current political climate in Australia favour the introduction of a gender quota on corporate boards? Although state involvement in corporations has been traditionally discouraged because they are private bodies, Australia's overall approach to legislation in this area is both public and pragmatic. This combination results in significant state intervention in corporate governance. It will also be argued that we may now be at a critical juncture due to the intense public interest in gender as a political issue. These two factors - the public pragmatism of statutory regulation of corporations in Australia and the current salience of gender as a political issue - may favour the introduction of a quota, even by a centre-right government.

Finally the optimal design of an Australian board gender quota will be explored, taking into account Australia's corporations law and corporate governance regime and comparing it to other jurisdictions which have promoted a gender quota in similar areas.

\section{BACKGROUND}

This article expands upon an article published in 2012 where the author advocated that gender quotas on boards should be seriously reconsidered for Australia. That article argued that the participation of women on boards is a measure of economic citizenship and democratic leadership, and therefore the 
percentage of women on boards should broadly reflect their workforce participation. $^{2}$

The present article primarily focuses upon literature, debates and policies which have been generated about this issue over the last five years.

Most of the studies of gender structures on corporate boards in Australia date from the early 1990s. ${ }^{3}$ In 1995, a study conducted by Korn Ferry and the Australian Institute of Company Directors ('AICD') showed that the percentage of women on boards was about 4 per cent. ${ }^{4}$ By 2010 the Australian Bureau of Statistics ('ABS') commented that there had been very little progress towards gender equality on boards, even though percentages had doubled to 8 per cent. The number of board seats had changed little from 121 seats in 2003 to 123 seats in $2010 .^{5}$

In 2012 the number of women on the boards of ASX 200 companies was about 10-13.8 per cent ${ }^{6}$ and still disappointingly low. ${ }^{7}$ Important structural and situational factors were (and are) impeding women's progress to corporate board positions. A serious debate about quotas was needed as part of a broader strategy to boost participation.

By 2012 some soft policy and regulatory options had been implemented, such as the ASX disclosure obligations and the mentoring programs conducted by the AICD. Further, collaborative approaches between corporations, government and civil society were generating a strong debate and there was considerable societal pressure for change. However, the need for a long-term plan was evident, owing to the complexities of the issue, the structural nature of the impediments, and the slow progression of women onto boards. As a consequence, it was contended by the present author that coercive measures

\footnotetext{
${ }^{2}$ Peta Spender, 'Gender Diversity on Boards in Australia: Waiting for the Great Leap Forward?' (2012) 27 Australian Journal of Corporate Law 22.

${ }^{3}$ The author has been undertaking research about women in corporations since the early 1990s. At that stage there was very little information about gender on boards apart from the material collected by Korn Ferry and the Australian Institute of Company Directors (AICD).

${ }^{4}$ Korn/Ferry International and the Australian Institute of Company Directors, Fourteenth Study of Boards of Directors, (1995), cited in Peta Spender, 'Women and the Epistemology of Corporations Law' (1995) 6 Legal Education Review 195, 205; and also in Peta Spender, 'Exploring the Corporations Law Using a Gender Analysis' (1996) 3 Canberra Law Review 82, 84.

5 Australian Bureau of Statistics, 'Gender Indicators, Australia: Leaders In Top 200 ASX Companies' (Cat 4125.0, Australian Bureau of Statistics, July 2011).

${ }^{6}$ See the discussion in Spender, above n 2, 28-30.

${ }^{7}$ Ibid 28.
} 
needed to be considered as an adjunct to soft options. ${ }^{8}$ To this end, it was argued that the quota debate should be reopened and informed by the experience of other countries such as Norway that had embraced the quota option. Since 2012, debate about gender quotas has spread like a prairie fire ${ }^{9}$ and is now commonplace. It is clear that a strong appetite for change persists, as demonstrated by the volume of commentary that has recently been published on this topic. ${ }^{10}$ There is enormous interest in the topic and it appears to be accelerating rather than diminishing.

\section{FRAMEWORK}

This article examines the existing institutional arrangements in Australia that predict, or militate against, the introduction of board gender quotas. Certain current institutional arrangements may predict future legislative gender quotas due to path dependence. ${ }^{11}$ 'Path dependence' refers to the formation of policy; once a policy path is taken, it may become 'locked in', as actors responding to new circumstances adjust their strategies to accommodate the prevailing pattern. ${ }^{12}$ In this context, 'path dependence' describes the influence of a particular set of factors such as corporate ownership structures, economic and market conditions, history, culture and political ideology that set the path for regulation. ${ }^{13}$ In the context of gender equality two paths converge - gender and corporate regulation. Institutional arrangements which favour the introduction of a gender quota for corporate boards include, for example, a

\footnotetext{
${ }^{8}$ Spender, above $\mathrm{n} 2,38$

${ }^{9}$ For an explanation of this epithet see Douglas Branson, 'A Corporate Palaeontologist's Look at Law and Economics in the Seventh Circuit' (1989) 62 Chicago-Kent Law Review 745, 745, quoted in Brian Cheffins, 'Corporations' in Peter Cane and Mark Tushnet (eds), The Oxford Handbook of Legal Studies (Oxford University Press, 2003) 485, 493.

${ }^{10}$ For example, if one enters the search terms 'gender' and 'quota' and 'boards' into a library search engine (which looks for newspapers and scholarly articles only, not web based documents) it generates over 10000 results since 1 January 2013.

${ }^{11}$ Siri Terjesen, Ruth V Aguilera and Ruth Lorenz, 'Legislating a Woman's Seat on the Board: Institutional Factors Driving Gender Quotas for Boards of Directors' (2015) 128 Journal of Business Ethics 233.

${ }^{12}$ Kathleen Thelen, 'Historical Institutionalism in Comparative Politics' (1999) 2 Annual Review of Political Science 369, 385.

${ }^{13}$ In relation to the regulation of corporations, see generally Curtis Milhaupt and Katharina Pistor, Law and Capitalism: What Corporate Crises Reveal about Legal Systems and Economic Development around the World (University of Chicago Press, 2008); Peter Hall and David Soskice, 'An Introduction to Varieties of Capitalism' in Peter Hall and David Soskice (eds), Varieties of Capitalism: The Institutional Foundations of Comparative Advantage (Oxford University Press, 2001).
} 
history of political gender quotas. ${ }^{14}$ For Terjesen, Aguilera and Lorenz the institutional arrangements that predict gender quotas for boards are the historical factors of greater family policy welfare provisions for women in the labour market, gender equality initiatives and left-leaning governments. ${ }^{15}$

In Australia, evidence suggests that some institutional arrangements favour the introduction of quotas, for example, a tradition of gender equality initiatives manifested in the WGE Act. On the other hand, countervailing tendencies, such as the lack of a political quota tradition, a possible ambivalence about affirmative action, and the predisposition to voluntary initiatives due to the characterisation of the issue as one of 'corporate governance', may discourage state intervention on gender grounds. ${ }^{16}$

Diffusion may be counterpoised against path dependence. The term 'diffusion' refers to the spread of policy initiatives from one jurisdiction to another. The central force behind diffusion is the uncertainty of policymakers - due to limited information and bounded rationality - about whether policies work. Thus there is a tendency to apply policies that have been implemented, and seem to work, in other countries. ${ }^{17} \mathrm{~A}$ process of diffusion is spreading gender quota laws from country to country, to transnational bodies such as the EU, and from public sector contexts to private boards. ${ }^{18}$ Diffusion is more likely to occur at a critical juncture. ${ }^{19}$ It is argued below that Australia is at this critical juncture now because of the intense public interest in and commentary about this issue, and the current salience of gender as a political issue.

The article also considers the justifications for quotas and argues that the enduring justifications for quotas are based on equality, parity and democratic legitimacy. These justifications may be distinguished from functionalist justifications about quotas which are, in the author's view, too fragile to support this initiative.

\footnotetext{
${ }^{14}$ Mari Teigen, 'Gender Quotas on Corporate Boards: On the Diffusion of a Distinct National Policy Reform' in Fredrik Engelstad and Mari Teigen (eds), Firms, Boards and Gender Quotas: Comparative Perspectives (Emerald Group Publishing, 2012) 115.

${ }^{15}$ Terjesen, Aguilera and Lorenz, above n 11.

${ }^{16}$ The voluntary initiatives are described in some detail in Spender, above n 2; see also other articles in this special edition.

17 Teigen, above n 14, 115, 117, citing Thelen, above n 12, 387.

${ }^{18}$ Ibid 119.

${ }^{19}$ Ibid 117, citing Thelen, above n 12, 387.
} 


\section{PREDictors OF Gender QUOTAS}

\section{A Gender Equality Initiatives}

A tradition of gender equality reforms paves the way for gender quotas. Whilst this tradition has been firmly established in Australia since the $1970 \mathrm{~s},{ }^{20}$ Charlesworth and Macdonald note that some important steps were taken in 2013 to develop Australia's gender equity infrastructure ${ }^{21}$ through enhanced reporting requirements under the WGE Act. ${ }^{22}$ The WGE Act includes equal remuneration as one of its principal objectives and is one of six 'gender equality indicators' ('GEIs') against which all large and non-public sector employers must report. Two of the relevant GEIs are the gender composition of the workforce, ${ }^{23}$ and the gender composition of governing bodies of relevant employers. ${ }^{24}$ Although it was feared that the reporting requirements would be watered down with the present government's declared determination to 'repeal ... red tape', the threatened repeal has not occurred so far. ${ }^{25}$ Internationally, increased labour participation rates among women only weakly correlate with the number of women in leadership positions in the corporate sector. ${ }^{26}$ Australian data reflect the same pattern. In September 2013, the women's employment rate in Australia was 55.8 per cent compared to 67.4 per cent for men. ${ }^{27}$ The employment rate for women aged 25 to 54 years in Australia (72.3 per cent) in the same period showed that it is low compared to the same cohort in similar economies, for example Scandinavia (around 80 per cent) and the

${ }^{20}$ For an overview of this tradition, see Jean du Plessis, James O’Sullivan and Ruth Rentschler, 'Multiple Layers of Gender Diversity on Corporate Boards: To Force or Not to Force?' (2014) 19(1) Deakin Law Review 1, 49-50.

${ }^{21}$ Sara Charlesworth and Fiona Macdonald, 'Women, Work and Industrial Relations in Australia in 2013’ (2014) 56 Journal of Industrial Relations 381, 391 relying upon Rubery's concept of 'gender-equality-friendly' policy and regulatory settings which promote women's empowerment and continuity in employment, including institutional arrangements and infrastructure such as childcare: see Jill Rubery, 'Gender and Regulation: The Use and Misuse of the Gender Equality Cause' (Paper presented at the 2nd Conference of the Regulating for Decent Work Network, International Labour Office, Geneva, 6-8 July 2011).

${ }^{22}$ Department of Employment, The Workplace Gender Equality (Matters in relation to Gender Equality Indicators) Instrument 2013 (No 1).

${ }^{23}$ Ibid Sch 1 Item 1.

${ }^{24}$ Ibid Item 2.

25 'Govt Avoids Fight over Gender Reporting', AAP General News Wire, 4 April 2014; 'Gender Reporting Not Part of Repeal: Govt.', AAP General News Wire, 19 March 2014.

${ }^{26}$ Rohini Pande and Deanna Ford, 'Gender Quotas and Female Leadership' (Background Paper, World Development Report 2012, World Bank, 2011) 5.

${ }^{27}$ Australian Bureau of Statistics, 'Labour Force Australia' (Cat No 6202.0, Australian Bureau of Statistics, September 2013). 
Netherlands (78.9 per cent). ${ }^{28}$ Similarly, the employment rate for Australian women with children under 16 years of age (62 per cent) is low in comparison with the OECD average (66 per cent). ${ }^{29}$

The debate about board gender quotas is focused upon a very particular slice of female economic participation, primarily women on the boards of ASX 200 companies. Achieving the representation in this segment may not deliver general welfare for women, although the effects of mentoring and symbolic representation may see a trickle-down in the labour force within the private sector, including corporations, and in the public sphere. ${ }^{30}$ Symbolic representation will be discussed in more detail below.

\section{CONTRAINDICATIONS FOR GENDER QUOTAS}

There are some contraindications for quotas in Australia. First, there is a perception of unfairness about affirmative action and a stigmatisation of beneficiaries that must be managed; secondly, quotas raise questions about the proportional or optimal regulation of the private sector.

\section{A A Perceived Unfairness?}

The main argument against quota reforms is that they are unfair or discriminatory and will bring undeserving and insufficiently qualified women into decision-making bodies. ${ }^{31}$ It is interesting to scrutinise this perception of unfairness. As noted by Terjesen, Aguilera and Lorenz, gender quota legislation must negotiate two interrelated ethical problems: first, that in a pre-legislation environment, women may be underrepresented despite their equal competence; and, second, that after quota legislation is passed, women may be appointed directors of companies, even though they are not the most qualified candidates. ${ }^{32}$ This dilemma challenges the centrality of merit as the criterion

\footnotetext{
${ }^{28}$ Organisation for Economic and Co-operative Development (OECD), LFS for Women Aged 24-54 Employment to Population Ratio (2013) OECD StatExtracts <http://stats.oecd.org/>.

${ }^{29}$ Organisation for Economic and Co-operative Development (OECD), Maternal Employment Rates (2012) OECD Family Database LMF1.2 <http://www.oecd.org/social/ soc/oecdfamilydatabase.htmlabour_market>.

${ }^{30}$ See the discussion in Nina Smith, 'Quota Regulations of Gender Composition on Boards of Directors' (2014) 12 CESifo DICE Report 42, 47-8.

${ }^{31}$ Eléonore Lépinard and Ruth Rubio-Marín, 'Gender Quotas: Towards Parity Governance?’ (Policy Brief No 2013/08, Robert Schuman Centre for Advanced Studies, European University Institute, 2013) 4.

${ }^{32}$ Terjesen, Aguilera and Lorenz, above n 11, 234.
} 
for the selection of candidates. However there has been a significant critique of the very concept of merit in the literature over many decades, ${ }^{33}$ and it is clear that the presence of men on boards may be for reasons other than merit, such as informal networking, or simply the accumulation of power. ${ }^{34}$ Khurana's study of US CEOs demonstrates homogeneity in their demographic characteristics such as gender, age, occupation, class and status ${ }^{35}$ which led Khurana to conclude that the process of recruitment was closed. ${ }^{36}$ This is not consistent with a merit-based system of recruitment.

Nevertheless, although mandated affirmative action programs may increase the representation of women on boards, the negative reactions to affirmative action of both beneficiaries and non-beneficiaries need to be carefully managed. ${ }^{37}$ Whelan and Wood have compared the negative reactions to affirmative action that are still observable in the US, despite the policy operating there for more than 30 years, and those in Norway, where there has been a general acceptance of quotas after only five years. ${ }^{38}$ While it is tempting to argue that the nonbeneficiaries will eventually adjust, the sense of grievance may be exacerbated by arguments that treat the recruitment of women directors as a zero-sum game. In other words, every time a woman is recruited a man misses out. ${ }^{39}$ The plausibility of this argument diminishes if the focus is upon parity rather than positive action on behalf of women. This argument will be explored below.

On the potential recipients' side, one of the major critiques of quotas is that they may stigmatise their beneficiaries. In the UK, for example, a House of Lords committee report opposed pursuing quotas except as an option of last resort because, among other things, the committee felt that they 'risk fostering the perception - though entirely incorrect — that women on boards were not there by merit' ${ }^{40}$ On the other hand, Dhir's survey of the women directors appointed

\footnotetext{
${ }^{33}$ See, eg, Clare Burton, Redefining Merit, Affirmative Action Agency Monograph No 2 (1988); Margaret Thornton, 'Affirmative Action, Merit and the Liberal State' (1985) 2 Australian Journal of Law and Society 28.

${ }^{34}$ Lépinard and Rubio-Marín, above n 31, 4.

${ }^{35}$ Rakesh Khurana, Searching for the Corporate Savior (Princeton University Press, 2002) 84.

${ }^{36}$ Ibid 29.

${ }^{37}$ Jennifer Whelan and Robert Wood, 'Targets and Quotas for Women in Leadership: A Global Review of Policy, Practice and Psychological Research’ (Research Paper, Centre for Ethical Leadership, Melbourne Business School 2012) $22<$ https://cel.edu.au/>.

${ }^{38}$ Ibid 27.

${ }^{39}$ See, eg, the speculation by Du Plessis, O’Sullivan and Rentschler that male directors will need to be removed from boards in the ASX 200 in order for the targets proposed by the Sex Discrimination Commissioner in 2010 to be met in the recommended period: above $n$ 20, 38 .

${ }^{40}$ House of Lords European Union Committee, UK Parliament, Women on Boards Report (2012) 27 <http://www.publications.parliament.uk/pa/ld201213/ldselect/ldeucom/58/58.pdf>.
} 
under Norway's quota legislation found that they did not feel stigmatised. ${ }^{41}$ Further, only a very small minority attributed any differential treatment to gender. ${ }^{42}$ One participant, for example, considered that all newcomers to an organisation would be subjected to enhanced scrutiny and to the expectation that they would 'earn [their] spurs'. ${ }^{43}$

\section{B Proportional Regulation of the Private Sector}

Although states have the power to control corporate elites and regulate corporate board membership by legislation, neoliberal values emphasise the private nature of corporate enterprise and assert that the role of the state should be confined to setting the basic rules of corporate conduct; the state should not assertively intervene in the operations of corporations. ${ }^{44}$ On this argument, the metric of shareholder value should be the primary impetus for corporate decision-making. Similar arguments are made about the proprietary rights of shareholders which protect them from undue state intervention. ${ }^{45}$

Neoliberalism features prominently in US debates about corporate regulation. ${ }^{46}$ In Australia, while neoliberal arguments exert some influence, legislators tend to be more focused upon public ordering and pragmatism than their US counterparts. ${ }^{47}$ This approach is 'public' in the sense that corporations are increasingly viewed as public bodies and legislation in Australia is not predicated upon a characterisation of them as private, contractually-constituted

\footnotetext{
${ }^{41}$ Aaron Dhir, 'Norway’s Socio-Legal Journey: A Qualitative Study of Boardroom Diversity Quotas' (Research Paper No 65, Legal Studies Research Paper Series, Osgoode Hall Law School, 2014) $31-5<$ http://papers.ssrn.com/abstract=2488153>.

${ }^{42}$ Ibid 33.

${ }^{43}$ Ibid.

${ }^{44}$ Eelke Michiel Heemskerk and Meindert Fennema, 'Women on Board: Female Board Membership as a Form of Elite Democratization’ (2014) 15 Enterprise \& Society 252, 260.

${ }^{45}$ Fredrik Engelstad, 'Limits to State Intervention into the Private Sector Economy: Aspects of Property Rights in Social Democratic Societies' in Fredrik Engelstad and Mari Teigen (eds), Firms, Boards and Gender Quotas: Comparative Perspectives (Emerald Group Publishing, 2012) 235, 260.

${ }^{46}$ Angus Corbett and Peta Spender, 'Corporate Constitutionalism' (2009) 31 Sydney Law Review 147, 148; Michelle Welsh et al, 'The End of the "End of History for Corporate Law”?' (2014) 29 Australian Journal of Corporate Law 147, 152-3.

${ }^{47}$ For a discussion of a pragmatism and public policy concerns in Australian corporate law, see Corbett and Spender, above $\mathrm{n} 46$. The differences between US corporate law and other common law jurisdictions are discussed in Jennifer Hill, 'Regulatory Show and Tell: Lessons from International Statutory Regimes’ (2008) 33 Delaware Journal of Corporate Law 819.
} 
associations. ${ }^{48}$ 'Pragmatism' describes the tendency of Australian corporate regulation to pragmatically respond to scandals and crises rather than being driven by principle or ideology. After a flurry of activity at the turn of the present century which sought to reform corporate law through a comprehensive economic policy framework, Australian corporate law has settled back into its usual cycle of reactive rather than proactive legislation, ${ }^{49}$ frequently 'track[ing] the contours of local scandals'. ${ }^{50}$ There is a general recognition that some interference with the market is a necessary compromise although the appropriateness of individual policy initiatives is often contentious. ${ }^{51}$ Importantly, state involvement in corporate activity has not withered away ${ }^{52}$ and the shift to federal legislation following a referral of power by the states in 2000 has probably intensified the involvement of the state in corporate governance. ${ }^{53}$

Consequently, Australian corporate law and governance is characterised by pragmatism and a public dimension that might justify higher levels of intervention by statutory regulation than in other jurisdictions. ${ }^{54}$

\section{JUSTIFICATIONS}

As discussed above, the international spread of corporate board quotas may occur by a process of diffusion which prompts changes in the social acceptance of public policies. This can occur through media action, ${ }^{55}$ or more broadly via

\footnotetext{
${ }^{48}$ David Ciepley, 'Beyond Public and Private: Toward a Political Theory of the Corporation' (2013) 107 American Political Science Review 139, 139; Welsh et al, above n 46.

${ }^{49}$ Sandra Berns and Paula Baron, Company Law and Governance: An Australian Perspective (Oxford University Press Australia, 1998) 50.

50 Jennifer Hill, 'The Persistent Debate about Convergence in Comparative Corporate Governance' [a review of Jeffrey N Gordon and Mark J Roe (eds), Convergence and Persistence in Corporate Governance (2004)] (2005) 27 Sydney Law Review 749, 751.

${ }^{51}$ Robert Baxt, 'Thinking about Regulatory Mix - Companies and Securities, Tax and Trade Practices' in Peter Grabosky and John Braithwaite (eds), Business Regulation and Australia's Future (Australian Institute of Criminology, 1993) 117, 118.

52 Stephen Bottomley, The Constitutional Corporation: Rethinking Corporate Governance (Ashgate, 2007) 33.

${ }^{53}$ Michael Whincop, An Economic and Jurisprudential Genealogy of Corporate Law (Ashgate, 2001) 16-17.

${ }^{54}$ Welsh et al, above n 46, 148, 163-4.

${ }^{55}$ Celia De Anca and Patricia Gabaldon, 'The Media Impact of Board Member Appointments in Spanish-Listed Companies: A Gender Perspective’ (2014) 122 Journal of Business Ethics 425.
} 
public commentary. ${ }^{56}$ If change is promoted by diffusion, what are the justifications for a gender quota?

\section{A Functionalist Justifications}

Most of the arguments made in support of gender quotas on boards are functionalist in the sense that they assert that 'women make a difference somehow' ${ }^{57}$ Logically, it would seem that the right to equality should be the primary justification; however, functionalist arguments dominate the literature. Suk suggests that the equality of opportunity justification may compel the prohibition of discrimination against women, but is usually insufficient to drive more robust pursuits of diversity, such as affirmative action or quotas. ${ }^{58}$

Functionalist arguments in this area focus upon the so-called 'business case' for women's representation on boards. Clearly the business case justification 'appeals to a culture steeped in shareholder value as the metric for corporate decision making'. ${ }^{59}$ It is difficult to 'sell' quotas which are justified only by moral or normative considerations. Moreover, the business case is appealing because it avoids the zero-sum mentality that accompanies equal opportunity claims. The business case is a story in which everyone wins, women get opportunities, and businesses get rich. It therefore ameliorates the negativity of the zero-sum analysis where women get opportunities at the expense of men. ${ }^{60}$

\section{B Healthy Scepticism about the Business Case}

As stated above, the business case for gender diversity on boards contends that having women on boards is good for business. This can be 'measured' by a multiplicity of factors such as financial performance, customer base or stakeholder relations. For example, when introducing a market initiative to encourage gender diversity in the Corporate Governance Principles and Recommendations, the ASX stated:

56 Jürgen Habermas, 'Three Normative Models of Democracy' in Seyla Benhabib (ed), Democracy and Difference: Contesting the Boundaries of the Political (Princeton University Press, 1996) 21.

${ }^{57}$ Lépinard and Rubio-Marín, above n 31, 4.

58 Julie C Suk, 'Gender Parity and State Legitimacy: From Public Office to Corporate Boards' (2012) 10 International Journal of Constitutional Law 449, 452.

59 Deborah L Rhode and Amanda K Packel, 'Diversity on Corporate Boards: How Much Difference Does Difference Make?’ (2014) 39 Delaware Journal of Corporate Law 377, 383.

${ }^{60}$ Suk, above n 58, 463-4. 
Research has shown that increased gender diversity on boards is associated with better financial performance. ${ }^{61}$

Chapple and Humphrey responded that this claim by the ASX

is puzzling because a positive association between gender diversity and performance has not been convincingly established in the available academic literature. ${ }^{62}$

Most academics and commentators who write about corporate gender quotas seem to feel compelled to address the business case. However, some of the claims made under the business case are outlandish, implausible, essentialist or based on very small samples. Examples of some of the claims are that women are less likely to tolerate corporate crime, women on boards are more caring and women on boards are less likely to engage in tax avoidance. ${ }^{63}$

Academics and commentators then commonly reject the methodology adopted by advocates of the business case. ${ }^{64}$ The methodology of the business case remains problematic because of the challenges it poses to logical assessment, including the difficulty in finding a counterfactual scenario, ${ }^{65}$ or applying the difference-in-difference method, ${ }^{66}$ or deciding whether a correlation proves causality, or whether a reverse causality is in operation. ${ }^{67}$ The classic reverse causality problem is demonstrated by the aforementioned ASX comment that corporations with women on their boards are stronger financial performers. The problem of determining causation lies in the fact that strong financial performers may encourage women to join their boards for all sorts of reasons, so the causative factors may actually operate in reverse: rather than board

61 ASX Corporate Governance Council, Corporate Governance Principles and Recommendations with 2010 Amendments (Australian Securities Exchange, $2^{\text {nd }}$ ed, 2010) 25.

${ }^{62}$ Larelle Chapple and Jacquelyn E Humphrey, 'Does Board Gender Diversity Have a Financial Impact? Evidence Using Stock Portfolio Performance’ (2014) 122 Journal of Business Ethics 709, 711.

${ }^{63}$ These claims are all based on published studies but have not been cited because it is not the author's intention to single out individual articles for critique.

${ }^{64}$ Note, for example, the comments of Chapple and Humphrey: '[W]e find no compelling evidence of a clear performance differential between firms with and without female directors': above $n$ 62, 710 .

65 Smith, above $\mathrm{n} 30,47$.

${ }^{66}$ Pande and Ford, above n 26, 22.

${ }^{67}$ Du Plessis, O’Sullivan and Rentschler, above n 20, 3-4. 
diversity driving profitability, the latter encourages the former. ${ }^{68}$ Chapple and Humphrey have suggested

that there are plausible circumstances in which a firm that is larger, more established and in a particular industry may 'trade up' to diversity as a business proposition, but not necessarily for clear-cut quantifiable economic reasons. ${ }^{69}$

Moreover, the performance of a corporation is multifaceted. For this reason the attribution of corporate performance to individuals may be misconceived and an example of the 'romance of leadership' where organisational performance is disproportionately attributed to the qualities of leaders. ${ }^{70}$ Moreover, corporate performance is often measured by the short-term reaction of the market to changes in board membership rather than long term financial performance. ${ }^{71}$

It can become dangerous when women are singled out because of their gender when the performance of a company is clearly multifaceted. For example, Du Plessis, Saenger and Foster state as follows:

What the actual effect of [the appointment of more women as senior executives and to boards] will be from a business point of view is impossible to predict. However, that women will have a bigger say in the corporate world in, say, five years' time, is beyond dispute. ... In fact, this prediction brings with it a huge responsibility on women to live up to the expectations that improved gender balance will lead to improvements. ${ }^{72}$

This statement typifies the problem with the business case. On the one hand, there is no certainty that women make a difference to business performance, yet it is on the basis of this justification that they are obliged to live up to our expectations and 'earn their stripes'. That is not a value that should be applied in this case. It is necessary therefore to examine more enduring justifications.

68 Jasmin Joecks, Kerstin Pull and Karin Vetter, 'Gender Diversity in the Boardroom and Firm Performance: What Exactly Constitutes a “Critical Mass?”' (2013) 118 Journal of Business Ethics 61, 65.

${ }^{69}$ Chapple and Humphrey, above n 62, 710.

${ }^{70}$ James Meindl, 'Reinventing Leadership: A Radical, Social Psychological Approach’ in J Keith Murnighan (ed), Social Psychology in Organizations (Prentice Hall, 1993) 89; James R Meindl, Sanford B Ehrlich and Janet M Dukerich, 'The Romance of Leadership' (1985) 30 Administrative Science Quarterly 78.

${ }^{71}$ Smith, above n 30, 46; Pande and Ford, above n 26, 27.

72 Jean du Plessis, Ingo Saenger and Richard Foster, 'Board Diversity or Gender Diversity? Perspectives from Europe, Australia and South Africa’ (2012) 17 Deakin Law Review 207, 249. 


\section{Enduring Justifications}

In the present author's view the best justifications for gender equality on corporate boards are normative, and include equality, parity and democratic legitimacy. Each of these will be discussed in turn.

\section{Equality}

The usual justification for state action in promoting gender equality on the boards of corporations recognises the fundamental right of equality between men and women that is guaranteed, for example, under article 3 of the International Covenant on Civil and Political Rights. ${ }^{73}$ The right to equality has a negative dimension that prohibits discrimination between women and men, and a positive dimension that legitimises affirmative action by specifically supporting persons who are members of the underrepresented sex.

While the right to equal treatment is a familiar and fundamental civil and political right, it is necessary to examine how that right can be re-articulated to justify changes in the private sector. This involves an analysis of parity and democratic legitimacy.

\section{Parity}

The notion of an underrepresented sex introduces the concept of parity. Parity reaffirms the unity, rather than division, of society by requiring that the two complementary halves of humanity (male and female) be represented. ${ }^{74}$ 'Parity democracy' is not primarily aimed at enhancing women's opportunities as individuals or even as a group. Its primary purpose is to legitimise the exercise of political, economic and social power by larger institutions. The democratic republic, as the largest institution, must represent all people — both male and female. The new model embraces gender balance as a collective democratic undertaking rather than as a means of achieving equal opportunity for a minority group. ${ }^{75}$

Drawing on Pateman's work on the sexual contract, ${ }^{76}$ Rodríguez-Ruiz and Rubio-Marín argue that the disqualification of women as citizens in the past was a central structural feature of the modern state, where autonomous male

\footnotetext{
73 Opened for signature 16 December 1966, UNTS 999 (entered into force 23 March 1976).

74 Blanca Rodríguez-Ruiz and Ruth Rubio-Marín, 'The Gender of Representation: On Democracy, Equality, and Parity’ (2008) 6 International Journal of Constitutional Law 287, 289.

${ }^{75}$ Suk, above n 58, 452, 455.

${ }^{76}$ Carole Pateman, The Sexual Contract (Stanford University Press, 1988).
} 
individuals could only thrive or continue to reproduce themselves socially by requiring women to perform tasks in the private sphere. It is only when women actively participate in the public sphere in significantly large numbers that the system will be forced to confront and solve the problems of dependency and social reproduction. Unless women are visibly participating in public institutions of the state, it can be assumed that the sexual contract is firmly in place. ${ }^{77}$

The limitations of parity as a democratic principle have been critiqued by intersectional analysis. ${ }^{78}$ When an intersectional perspective is applied to gender quotas, it recognises that 'identity categories such as gender, race, ethnicity, class, and sexuality are mutually constituted and cannot be added together' ${ }^{79}$ Therefore the goals of improving women's representation and minorities' representation might run against the other. ${ }^{80}$

In relation to gender quotas on boards, parity democracy is used by the state as its rationale when brokering the quota initiative. It does so to legitimise its own authority and to derivatively bolster the legitimacy of complying corporations.

The operation of parity as a constitutionalised concept is exemplified by France. There, the first attempt to legislate for corporate gender quotas was invalidated by the Conseil Constitutionnel in 2006. ${ }^{81}$ Despite the fact that the French constitution had been amended in 1999 to permit gender parity in elected office, the court viewed corporate gender quotas as a separate issue from parity in political institutions. Thus, a further constitutional amendment was required before corporate gender quotas became constitutionally viable. ${ }^{82}$ A 2008 constitutional amendment provided that the law should promote equal access to 'positions of professional and social responsibility' as well as elected office. $^{83}$ There was some resistance to the 2008 constitutional amendment because it raised the question of whether 'the principle of parity in social and professional matters' really belonged in the Constitution, 'which determines the

\footnotetext{
${ }^{77}$ Rodríguez-Ruiz and Rubio-Marín, above n 74, cited by Suk, above n 58, 456-7.

${ }^{78}$ Eléonore Lépinard, 'For Women Only? Gender Quotas and Intersectionality in France’ (2013) 9 Politics \& Gender 276, 276.

${ }^{79}$ Evelyn M Simien, 'Doing Intersectionality Research: From Conceptual Issues to Practical Examples’ (2007) 3 Politics \& Gender 264, 265.

${ }^{80}$ Lépinard, above $n$ 78, 277. This important and interesting issue is discussed in Michael Adams, 'Board Diversity: More than a Gender Issue' (2015) 20(1) Deakin Law Review 123. Therefore the present author will not dwell upon it.

${ }^{81}$ Conseil constitutionnel, decision $n^{0}$ 2006-533 DC, March 162006 reported in JO, 24 March 2006, 4446.

${ }^{82}$ Suk, above n 58, 457-9.

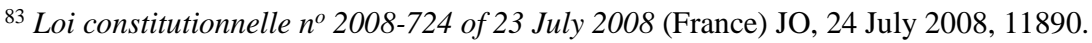


organization of public power' ${ }^{84}$ Nevertheless the supporters of the guarantee of parity in professional and social responsibility secured the constitutionalisation of the right, even though it had a significant operation in the private sphere.

The French example is instructive, both instrumentally and normatively. Instrumentally, the legislation supporting the corporate gender quotas has been successful in increasing the number of women on boards by a healthy percentage. ${ }^{85}$ Normatively, it was achieved by a social and constitutional accord, which, it is argued, allows equal opportunity to facilitate 'democratic solidarity, instead of alienating those whose opportunities appeared diminished by the new quotas' ${ }^{86}$

The moral of the story is that looking beyond the business case can sometimes yield remarkable dividends.

\section{Democratisation OF Elite Networks - Movement from Public to Private Boards}

Quotas may also be justified by the need for democratic legitimacy. Applying de Tocqueville's analysis, Heemskerk and Fennema argue that a female presence on corporate boards acts as a democratisation of elite social networks. According to this theory, the state acts as a broker to break down elites, which allows for movement by women from public institutions into private firms. It

\footnotetext{
${ }^{84}$ Suk, above n 58, 459, attributing theseremarks to Jérome Chartier in the French National Assemby, 27 May $2008<$ http://www.assemblee-nationale.fr/13/cra/2007-2008/170.asp> (in French).

${ }^{85}$ In January 2011 France adopted a corporate board quota law which reserved at least 40 per cent of the seats for each gender on the boards of all listed companies, companies with more than 500 employees or revenues exceeding $€ 5$ million. The quota is to be realised within six years. An interim regulation requires a minimum representation of 20 per cent women by the end of 2013, and a full implementation from 2016: Teigen, above n 14, 128. Since the introduction of quotas in 2011, the percentage of women serving on boards of directors or supervisory boards of CAC 40 companies in France has risen by 7.4 points. In five years, the proportion of women in these bodies has tripled. See Ethics \& Boards, Place des Femmes dans les Conseils d'Administration et de Surveillance (Post AG 2008 - 2013) (12 June 2014) Ethics \& Boards <http://www.ethicsandboards.com/etudes/101-place-des-femmes-dans-les-conseilsd-administration-et-de-surveillance-post-ag-2008-2013-1er-juin-2014> .

${ }^{86}$ Suk, above n 58, 464.
} 
does so to legitimise the authority of transnational bodies,${ }^{87}$ states and corporate elites.

In Australia, this may be demonstrated by the movement of women from public sector boards onto private boards. In this case, the state has paved the way by appointing women to the boards of government-controlled firms which constitutes an exogenous democratisation of the corporate elite imposed by the political elite.$^{88}$ In discussing the movement of women from public to private boards in Europe, Heemskerk and Fennema comment:

State-controlled firms served as bridgeheads for female politicians to enter the corporate elite. Once their presence became more accepted, they spread to other businesses as well. By the mid-1990s, reluctant support for female inclusion emerged among the corporate elite, which led to increased democratization from within. ${ }^{89}$

In Australia the appointment of women to the boards of state-owned enterprises and not-for-profit companies also acted as a bridgehead to corporate board positions. The early imposition of quotas for the state-controlled bodies allowed a discussion about quotas to flow from the public sector into the private sector. For example, targets were set in 2010 for Australian public sector boards and they have been realised ahead of time. As at 30 June 2013, 41 per cent of Australian government board positions were held by women, exceeding the 40 per cent by 2015 target set by the federal government in $2010 .{ }^{90}$

\footnotetext{
${ }^{87}$ The democratic legitimacy argument may also be mobilised at the transnational level. For example, the draft directive issued by the European Commission on 14 November 2012 demonstrates that the EU Commission is now ready to adopt an obligatory legal solution. The justification is, in part, gender parity which may extend to economic governance at the EU level. As stated by Szydło: 'Because the EU mode of governance is characterised by the broad participation of self-interested private companies and corporations, ... the institutions that form part of this governance system must themselves be configured appropriately. Otherwise, the EU's economic governance will not be properly and democratically legitimized': Marek Szydło, 'Constitutional Values Underlying Gender Equality on the Boards of Companies: How Should the EU Put These Values into Practice?' (2014) 63 International and Comparative Law Quarterly 167, 184.

${ }^{88}$ Heemskerk and Fennema, above n 44, 255.

${ }^{89}$ Ibid.

${ }^{90}$ Office for Women, 'Gender Balance on Australian Government Boards Report 2012-2013' (Research Report, Australian Government Department of Families, Housing, Community Services and Indigenous Affairs, August 2013) 2.
} 
Therefore, in conclusion, parity and democratic legitimacy justifications for board gender quotas are more likely to endure than functionalist arguments based on the business case.

\section{Representation - What Do We Achieve by HAVING WOMEN ON BOARDS?}

The next question concerns what we achieve by having women on boards. It is evident that placing women on the boards of major corporations perpetuates elite leadership. Although this type of leadership may differ from the masculinist model of the 'heroic champion with extraordinary stature and vision', ${ }^{91}$ we should not necessarily expect that it will improve women's wellbeing overall, since the women involved do not represent a particular constituency (unlike a political constituency). What should we then expect?

When a woman is appointed to a board there is an immediate direct increase in female representation in leadership positions. This is what Pitkin referred to as descriptive representation. Thus, where more board members are recruited from particular diverse demographic groups in society, the more democratic that society becomes in terms of descriptive representation. ${ }^{92}$ However, a question of substantive representation ${ }^{93}$ also arises. It is asked whether the representation of women's policy interests can be improved by increasing the proportion of female leaders through quotas. ${ }^{94}$ This is a complex issue for women on corporate boards because, as Lépinard and Rubio-Marín observe,

there is no valid research to show that women, as a collective, systematically have a different approach to that of men when performing as politicians, leaders or managers. ${ }^{95}$

A third and preferable type of analysis is associated with the concept of symbolic representation: the concept that, when women are included in decision-making bodies and are therefore visible in the public sphere, this signals a change to traditional conceptions of authority, citizenship and norm

\footnotetext{
${ }^{91}$ Lee Bolman and Terrence Deal, Leading with Soul: An Uncommon Journey of Spirit (JosseyBass, 1995) 5, cited by Nancy Adler, 'Global Leadership: Women Leaders' (1997) 37 Management International Review 171, 173.

${ }^{92}$ Hanna Fenichel Pitkin, The Concept of Representation (University of California Press, 1967) 60.

${ }^{93}$ Ibid 222.

${ }^{94}$ Pande and Ford, above n 26, 5.

${ }^{95}$ Lépinard and Rubio-Marín, above n 31, 5.
} 
creation..$^{96}$ This potentially creates a public image of feminine leadership, which has the potential to generate new conceptions of citizenship and democracy. ${ }^{97}$

\section{SHOULD THE INTRODUCTION OF A QUOTA BE EXPECTED IN AUSTRALIA ANy TIME SOON?}

While the introduction of a gender quota for corporate boards may to some extent depend on the progress of voluntary initiatives, it is pertinent to ask whether our political/policy bodies are amenable to diffusion, so as to allow gender quota policy to be learnt from other jurisdictions. It is said that diffusion is more likely to occur at a 'critical juncture' ${ }^{98}$ Major change is possible at a critical juncture, which differentiates it from a normal period of historical change. ${ }^{99} \mathrm{~A}$ critical juncture can bring about abrupt institutional change, as it presents leaders with an opportunity to enact new plans and realise new ideas by embedding them in established institutions. ${ }^{100}$ It is argued below that we are at such a critical juncture now, first, because of the intense public interest in and commentary about this issue; and, second, because of the current salience of gender as a political issue.

\section{A The Current Political Climate in Australia}

Although Terjesen predicts that quotas are more likely to be developed by leftleaning governments, ${ }^{101}$ they are often advanced by centre-right parties, Norway being a prominent example. The first initiative to introduce quota regulation for corporate boards in Norway came in a consultation audit of the Gender Equality Act in 1999 by the minority Conservative-Centre government coalition. A new motion was sent for consultation by the Labour Party government in 2001, but the final adoption of the quota ruling was based on a motion from 2001 presented to Parliament by the new Conservative Centre government coalition in 2003. ${ }^{102}$

\footnotetext{
${ }^{96}$ Pitkin, above n 92, 92.

${ }^{97}$ Lépinard and Rubio-Marín, above n 31, 5.

${ }^{98}$ Teigen, above n 14, 117, citing Thelen, above n 10, 387.

${ }^{99}$ Michael Gorges, 'The New Institutionalism and the Study of the European Union: The Case of the Social Dialogue' (2001) 24 West European Politics 152, 156.

100 John Hogan, 'Remoulding the Critical Junctures Approach' (2006) 39 Canadian Journal of Political Science / Revue Canadienne de Science Politique 657, 657.

101 Terjesen, Aguilera and Lorenz, above n 11, 239-42, 243.

102 Teigen, above n 14, 123.
} 
The negotiation between Angela Merkel's Christian Democrats (CDU) and the centre-left Social Democrats (SPD) in Germany in 2013 also demonstrated the potential for this policy to be generated from the centre-right. This resulted in a proposal that, as of 2016, 30 per cent of new appointments to the supervisory boards of publicly-traded German companies must be women. ${ }^{103}$

In Australia, a call for a 40 per cent quota of women on boards was made in 2010 by Elizabeth Broderick, the Sex Discrimination Commissioner. ${ }^{104}$ The current Treasurer, Joe Hockey, who was at that time in opposition, also backed quotas, suggesting that a quota of 30 per cent was appropriate. ${ }^{105}$ However, the then Prime Minister, Julia Gillard, said that government policy would not be changing.

We are strenuously urging the private sector to act to get more women onto their boards. I view regulating as the last option — I want to see selfmotivated change from Australian companies. ${ }^{106}$

\section{B A Critical Juncture}

Australia has reached a critical juncture in gender politics since the quota proposal was made by Elizabeth Broderick in 2010. Although gender issues were submerged during the 2010 federal election campaign when Prime Minister Gillard studiously avoided raising them, ${ }^{107}$ gender re-emerged as an overt political issue in Australia during 2011 and 2012 when it became central to the construction of the now deposed Prime Minister, Tony Abbott, 'both by friends and enemies'. ${ }^{108}$ This culminated in the famous misogyny speech delivered by Julia Gillard in the House of Representatives on 10 October 2012

\footnotetext{
103 'CDU and SPD Agree on Gender Quota in German Boardrooms', Spiegel Online (online), November 182013 <http://www.spiegel.de/international/germany/cdu-and-spd-agree-ongender-quota-in-german- boardrooms-a-934155.html> .

104 'PM against Quotas for Women on Boards' The Australian (online) 9 March 2011 $<$ http://www.theaustralian.com.au/news/latest-news/pm-against-quotas-for-women-onboards/story-fn3dxity-1226018170923>.

105 'Hockey Backs Quota for Women on Boards', The Sydney Morning Herald (online) 8 March $2011<$ http://www.smh.com.au/national/hockey-backs-quota-for-women-on-boards-20110308 -1bm6i.html>.

106 'PM against Quotas for Women on Boards', above n 104.

${ }^{107}$ Marian Sawer, 'Misogyny and Misrepresentation: Women in Australian Parliaments' (2013) 65 Political Science 105, 115.

108 Ibid 113.
} 
and directed at Mr Abbott when he was Leader of the Opposition. ${ }^{109}$ Julia Gillard said in part:

I will not be lectured about sexism and misogyny by this man. I will not. And the Government will not be lectured about sexism and misogyny by this man. Not now, not ever. The Leader of the Opposition says that people who hold sexist views and who are misogynist are not appropriate for high office. Well I hope the Leader of the Opposition has got a piece of paper and he is writing out his resignation. Because if he wants to know what misogyny looks like in modern Australia, he doesn't need a motion in the House of Representatives, he needs a mirror. ${ }^{110}$

The reception of the speech transformed it from a political exchange into the makings of a critical juncture. The significance of the speech was largely missed by the Australian press gallery but it attracted worldwide attention and commentary and in just 10 days it had been watched by more than 2 million viewers on YouTube. ${ }^{111}$

As McLean and Maalsen argue,

although there have been vocal female politicians before Gillard, such a direct speech on sexism and misogyny has not been delivered in the House of Representatives prior to this, and certainly not one that dealt with gender related shame in such a direct way. ${ }^{112}$

The events surrounding Julia Gillard's prime ministership, and the misogyny speech in particular, made gender the subject of public commentary in an unprecedented way. This, as argued above, produced a critical juncture. Although Australia does not have a political quota tradition ${ }^{113}$ and, at the time of writing, the number of women in State and federal parliaments has fallen from its 2009 peak, ${ }^{114}$ the public is becoming more outspoken about female representation in politics. After the federal election in September 2013 the new Prime Minister, Tony Abbott, received considerable criticism because of the

109 ‘Transcript of Julia Gillard’s Speech’, The Sydney Morning Herald (online), 10 October 2012, $<$ http://www.smh.com.au/federal-politics/political-news/transcript-of-julia-gillards-speech20121010-27c36.html>.

110 Ibid.

${ }^{111}$ Sawer, above n 107, 113.

112 Jessica McLean and Sophia Maalsen, 'Destroying the Joint and Dying of Shame? A Geography of Revitalised Feminism in Social Media and Beyond' (2013) 51 Geographical Research 243, 251.

113 Sawer, above n 107, 106.

114 The proportion of women in Australia parliaments (in all houses) peaked at 31 per cent in 2009 but slid to 28 per cent by February 2013: ibid. 
decline in the number of women in the Ministry. Only one female Minister was appointed - Julie Bishop, the Minister for Foreign Affairs. This aspect of the new Ministry attracted considerable criticism from both the traditional and social media.

The conservative stand taken to gender issues by the Liberal/National Coalition government prior to the deposition on 14 September 2015 of the Prime Minister, Tony Abbott, may be moderated by the controversy that the issue has generated. It is well known that Abbott had difficulty garnering electoral support from women. ${ }^{115}$ Polling showed that considerably more women disapproved of his handling of the job of Prime Minister (54 per cent) than approved (33 per cent). ${ }^{116}$ This was an unrelenting theme in Abbott's conversation with the electorate.

Legislation for gender quotas on boards is a progressive gender policy. It is not inconceivable in the current climate that a regenerated Liberal/National Coalition may embrace this policy.

\section{Designing the Quota}

There are several elements that must be considered when deciding a gender quota. These include the role of soft options and incentives, the cohort of companies that should be subject to the quota, the timeframes within which the quota should be achieved and the sanctions that should be applied if the quota is not fulfilled.

Most commentators accept that a 40 per cent quota is appropriate when benchmarked against women's participation in the labour market, which currently stands at around 55.8 per cent. ${ }^{117}$ The companies in the ASX 200 should be the target group because this cohort is a standard measure used by investors to model the Australian share market and has been used for some time to measure gender diversity on boards, including by the ABS.

Is the glass half empty or half full? The percentage of female directorships on ASX 200 boards was 18.6 per cent at 30 September 2014. Given that the figure

\footnotetext{
115 William Bowe, 'Poll Bludger: Abbott's “Women Problem”' on Crikey (8 August 2014) $<$ http://www.crikey.com. au/2014/08/08/poll-bludger-abbotts-women-problem>.

116 Roy Morgan Research, 'Australians Support Tony Abbott as PM over Bill Shorten - but Neither Leader Much Liked' (Public Opinion Poll, No 6207, 27 April 2015).

117 Australian Bureau of Statistics, 'Labour Force Australia' (Cat No 6202.0, Australian Bureau of Statistics, September 2013).
} 
was relatively static between 2003 and 2010, at around 8.3-8.4 per cent, any discernible annual increase improves the situation significantly. There have been some years of dramatic improvement, for example the 580 per cent increase between 2010 and 2011. However, before we pop the champagne corks it must be noted that the numbers rose from a very low base in 2009, ${ }^{118}$ and that the ASX 200 boards are still overwhelmingly dominated by men. ${ }^{119}$

When projected over the last 10 years, the increase in female participation on the boards of ASX 200 companies is occurring at a rate of approximately 1 per cent a year. On this basis, ${ }^{120}$ it can be estimated that, assuming the current level of annual growth, optimal gender representation will take about another 22 years to attain. This is unacceptable because it does not allow the current generation of women entering the management of companies to aspire to board membership within their own working lifetimes. Therefore, 22 years is too long and should, at least, be cut in half to allow the current generation of aspiring female managers to attain board positions. This would be a similar timeframe to that adopted by Norway.

The reform should occur as a composite. That is, the quota should be contingent upon the failure of voluntary initiatives (with incentives created by public procurement rules). Businesses should know that a contingent voluntary scheme has begun and that the quota will operate from a clear point in the future if the targets have not been achieved. The legislation should set timeframes for two phases as follows:

Phase 1 - a five-year period during which voluntary initiatives and incentives are in place to achieve a minimum target of 40 per cent of each gender on ASX 200 boards.

Phase 2 - the imposition of a quota at the conclusion of a further fiveyear period enforced by sanctions for non-compliance.

\footnotetext{
${ }^{118}$ As stated by Du Plessis, O’Sullivan and Rentschler, 'despite the striking 580 per cent uplift in female appointments during 2010 and 2011, the real percentage of female directors across the entire ASX 200 increased only 5.1 per cent (from 8.3 per cent at the start of 2010 to 13.4 per cent by the end of 2011)': above n 20, 39 .

${ }^{119}$ Ibid 49-50.

120 This is a rather simplistic analysis of the progression of women onto the boards of the ASX 200 and the author recommends that readers look at the detailed analysis provided by $\mathrm{Du}$ Plessis, O’Sullivan and Rentschler, ibid 35-43.
} 


\section{A Phase 1 - Expanding Voluntary Initiatives and Creating Incentives}

In certain contexts soft measures can work to achieve the requisite target. For example Finland has reached a quota of more than 25 per cent relying largely on soft measures such as the 'comply or explain' provisions in the Finnish Corporate Governance Code ${ }^{121}$ However, the Finnish legislation covers stateowned companies and excludes private companies. ${ }^{122}$ Because (as discussed above) the state acts as a bridgehead for women moving onto private boards, it is often easier for state-owned corporations to reach the quota than for privately-owned corporations.

It is suggested that the Australian government should encourage the continuation of voluntary initiatives, and could accelerate the attainment of the target by additional incentives which link board composition to public procurement. For example, the federal and Victorian governments have recently linked tenders for government legal services to the performance of 5 per cent of the value of the contract as pro bono legal work. ${ }^{123}$ This initiative has been successful in increasing the uptake of pro bono legal work by private firms. Similarly, the Spanish government has introduced a board gender target based on a 'comply or explain' regulatory approach which gives access to public contracts to companies that have achieved the designated target. ${ }^{124}$ The percentage of female directors on IBEX-35 company boards in Spain has risen from 6.4 per cent in 2007 to 10.1 per cent in $2010 .{ }^{125}$ Although there has been some criticism of the Spanish approach because the legislative requirement is treated as a recommendation rather than an obligation (thereby potentially

121 European Parliament Resolution of 6 July 2011 on Women and Business Leadership (2010/2115(INI)), [6]: This resolution '[w]elcomes Finland's Corporate Governance Code, under which firms' decision-taking bodies must contain both male and female representatives and there must be public disclosure of any non-compliance; notes that, because of the code, the proportion of women on Finnish firms' decision-taking bodies is now 25 per cent and that, since the introduction of the code was announced, the proportion of stock exchange-listed firms with women on supervisory or management boards has increased from $51 \%$ to about $70 \%$ '. The Resolution is cited by Du Plessis, Saenger and Foster, above n 72, 216 fn 61.

${ }^{122}$ Act 609/1986 on Equality between Women and Men (Finland).

123 National Pro Bono Resource Centre, Pro Bono Provisions in Government Tender Arrangements for Legal Services (September 2013) National Pro Bono Resource Centre $<$ http://www.nationalprobono.org.au/page.asp?from=3\&id=274>.

${ }^{124}$ Constitutional Act 3/2007 of March 22 (Spain), art 75 ('Gender Equality Act 2007’). See Celia De Anca and Patricia Gabaldon, 'The Media Impact of Board Member Appointments in Spanish-Listed Companies: A Gender Perspective’ (2014) 122 Journal of Business Ethics 425, 430.

${ }^{125}$ Instituto de la Mujer (2011) cited by Celia De Anca and Patricia Gabaldon, above n 124. 
lowering the likely uptake), ${ }^{126}$ rewarding private sector performance of social responsibilities by giving access to government contracts can be a very effective incentive.

\section{B Phase II - A Contingent Quota Enforceable by Sanctions}

If the target is not reached within the requisite timeframe, a further period would be set within which companies would have to comply with the quota, failing which sanctions would be imposed. Following the Norwegian example, a five-year period could be set to allow voluntary initiatives to operate, followed by the introduction of a quota which would be imposed after a further five-year period had elapsed.

A survey of the sanctions imposed under gender quota laws demonstrates a considerable range and versatility of approaches. For example, some jurisdictions, such as the Netherlands and Spain, impose a 'comply or explain' model, so that if the company does not comply with the target it must justify this in its annual report. Shareholders can then take action to change the board's composition, and stakeholders can apply external pressures to comply. ${ }^{127}$ In France, an appointment of board members in violation of the quota will be void, ${ }^{128}$ however resolutions by a board that is not composed in accordance with the statutory provisions will still be effective. ${ }^{129}$ Attendance fees for board members may not be paid until lawful composition of the board is reached. ${ }^{130}$ Similarly, in Belgium, non-compliance with the quota is penalised by the nullity of the appointment of the new director, and some of the directors' benefits are suspended. ${ }^{131}$ An EU Directive has suggested that administrative fines should be imposed and a judicial body empowered to make a declaration

\footnotetext{
${ }^{126}$ Pande and Ford, above n 26, 35.

127 Tineke Lambooy, '30 Percent Women on Boards: New Law in the Netherlands' (2012) 9 European Company Law 53, 63; Celia De Anca and Patricia Gabaldon, above n 124.

${ }^{128}$ Code de Commerce [French Commercial Code] L225-18-1 (para 1), cited by Du Plessis, Saenger and Foster, above n 72, 211.

${ }^{129}$ Code de Commerce [French Commercial Code] L225-18-1 (para 2, sentence 1) cited by Du Plessis, Saenger and Foster, ibid 211.

${ }^{130}$ Code de Commerce [French Commercial Code] L225-18-1 (para 2, sentence 2) cited by Du Plessis, Saenger and Foster, ibid.

${ }^{131}$ Lambooy, above n 127, 58.
} 
that the election of non-executive directors contrary to the quota provisions is a nullity. ${ }^{132}$

In relation to Norway, Teigen has argued that ' $\mathrm{t}]$ he fairly tough sanctions set up for breaking the law are probably an important factor on [sic] why the implementation of the quota law went smoothly'. ${ }^{133}$ Importantly, enforcement of the law in Norway follows a three-step model. First, a company not fulfilling the quota target may receive several warnings; then the Business Register may impose a fine; and, finally the company will be subject to forced dissolution. ${ }^{134}$ Although the sanction of forced dissolution may appear to be draconian, there have been no cases where any steps have been taken to impose sanctions. ${ }^{135}$

The Norwegian system of sanctions is a good model to adopt because it applies a stepped series of sanctions which escalate with protracted non-compliance. This is consistent with the responsive approach which is commonly used to regulate corporations in Australia. Responsive regulation aims to achieve optimal engagement by users because of its focus upon compliance rather than punishment. This gives it the advantage of preserving the trust, goodwill and cooperation of businesses which are seeking to comply with the regulations. However, in the event that a business is non-compliant, and unresponsive to an approach based on dialogue and persuasion, the regulator escalates responses up the multi-layered 'enforcement pyramid', each step of which imposes tougher sanctions upon the non-complying business. ${ }^{136}$

Further research into this area is needed. For example EU institutions must act in accordance with the principle of proportionality when designing the means for practical implementation of gender parity. ${ }^{137}$ It would be useful to consider how responsive regulation and proportionality may operate in tandem to secure an efficacious and fair system of sanctions. Naturally, commentators differ as to whether particular sanctions are effective and/or fair. ${ }^{138}$

\footnotetext{
${ }^{132}$ European Commission Brussels, Proposal for a Directive of the European Parliament and of the Council (14 November 2012) art 6.

133 Teigen, above n 14, 124.

134 Ibid 124-5.

${ }^{135}$ Report of the Register for Business Enterprises (Norway), cited in Teigen, ibid 125.

${ }^{136}$ Ian Ayres and John Braithwaite, Responsive Regulation: Transcending the Deregulation Debate (Oxford University Press, 1992) 21-7.

137 Treaty on European Union, opened for signature 7 February 1992, [2012] OJ C 326/18 (entered into force 1 November 1993), art 5.

${ }^{138}$ Compare Szydło's view about the proportionality of the 'comply or explain' sanctions in the Netherlands and Spanish systems with Lamboy's view that the lack of hard sanctions in the Netherlands law is 'disappointing' and Pande and Ford's view that the Spanish sanctions had
} 


\section{Conclusion}

The time is ripe for Australia to legislate for mandatory gender quotas for corporate boards. Although Australian policy makers have favoured the use of voluntary initiatives to increase the participation of women on boards, progress is still too slow to satisfy the strong public appetite for change. The path of voluntary initiatives has been followed due to, among other things, a reticence on the part of government to intervene in an operational issue of corporate governance and an ambivalence about affirmative action. However, Australia has developed a relatively robust pattern of legislative intervention in corporate law and Australian policy makers may be amenable to allowing the diffusion of gender quota policy from other jurisdictions that have successfully made the transition. In fact, they may welcome the change because the social debate has reached a critical juncture where gender has re-emerged as a salient political issue and there is a strong appetite for change which may influence political leaders. Legislation for board gender quotas for ASX 200 companies could be phased in, with clear timeframes which are contingent upon the failure of voluntary initiatives.

The change should be justified by recourse to enduring values such as parity, equality and democracy rather than misconceived functionalist arguments based upon the business case. The participation of women on boards is a measure of women's economic participation and democratic leadership. The leadership that they provide is symbolic but has the potential to generate new and vital conceptions of citizenship and democracy.

only resulted in a 'little' increase in female board representation: Szydło, above n 87, 186;

Lambooy, above n 127, 63; Pande and Ford, above n 26, 35. 